\title{
KEMAMPUAN POLRI MEMPERSIAPKAN TEKNIS PERSONIL PENYIDIK TINDAK PIDANA LINGKUNGAN HIDUP
}

\author{
Oleh: \\ Sumaidi *
}

\begin{abstract}
ABSTRAK
Salah satu tindak pidana adalah Pengrusakan dan pencemaran lingkungan hidup yang sampai saat ini sangat membawa dampak bagi masyarakat, maka dari itu diperlukan penegakan hukum terhadap kasuskasus yang tergolong tindak pidana lingkungan hidup.Kemampuan penegak hukum sangat penting dalam melakukan penyidikan dan penyelidikan terhadap tindak pidana lingkungan hidup. Penyidik lingkungan hidup, selain diharapkan memiliki kemampuan teknis yang memadai dalam pengumpulan bukti-bukti atas terjadinya suatu tindak pidana di bidang perlindungan dan pengelolaan lingkungan hidup, juga diharapkan memiliki pemahaman yang baik atas peraturan perundang-undangan yang berlaku, sekaligus mampu menjaga integritas, kredibilitas, dan kode etik dalam melaksanakan tugas utamanya, yaitu mencari kebenaran dan menegakkan keadilan demi melindungi kepentingan pelestarian fungsi lingkungan hidup.
\end{abstract}

Kata Kunci : Penyidik Polri, Tindak Pidana. Lingkungan Hidup

\section{A. Latar Belakang}

Manusia adalah mahluk sosial, hidup berkelompok, membuat aturan-aturan`yang disepakati bersama. Ternyata diantara kelompok itu ada yang tidak mau mematuhi aturan bersama, sehingga timbul masalah siapa yang berkewajiban untuk memperbaiki dan menertibkan kembali anggota kelompok yang telah melanggar. Dari pemikiran ini kemudian timbul Polisi, baik organnya maupun tugasnya untuk memperbaiki dan menugaskan tatasusunan kehidupan masyarakat tersebut. ${ }^{1}$

Salah satu tindak pidana adalah Pengrusakan dan pencemaran lingkungan hidup yang sampai saat ini sangat membawa dampak bagi masyarakat, maka dari itu diperlukan penegakan hukum terhadap kasus-kasus yang tergolong tindak pidana lingkungan hidup.Kemampuan penegak hukum sangat penting dalam melakukan penyidikan dan penyelidikan terhadap tindak pidana lingkungan hidup. Penyidik lingkungan hidup, selain diharapkan memiliki kemampuan teknis yang memadai dalam pengumpulan bukti-bukti atas terjadinya suatu tindak pidana di bidang perlindungan dan pengelolaan lingkungan hidup, juga diharapkan memiliki pemahaman

\footnotetext{
* Pengajar Fakultas Hukum UNBARI

${ }^{1}$ Warsito Hadi Utomo, Hukum Kepolisian di Indonesia. Prestasi Pustaka Publisher, Jakarta, 2005, hal 5
} 
yang baik atas peraturan perundang-undangan yang berlaku, sekaligus mampu menjaga integritas, kredibilitas, dan kode etik dalam melaksanakan tugas utamanya, yaitu mencari kebenaran dan menegakkan keadilan demi melindungi kepentingan pelestarian fungsi lingkungan hidup.

Dalam penegakan hukum terhadap tindak pidana lingkungan sering terjadi kendalakendala yaitu :

1. pengetahuan dan keterampilan penyidik;

2. lokasi kejadian yang seringkali sulit dijangkau yang berimplikasi pada biaya;

3. waktu kejadian tindak pidana yang sangat cepat, yang umumnya terjadi pada tindak pidana pembuangan limbah cair, sehingga menyulitkan dalam hal pengumpulan barang bukti;

4. pengumpulan bukti ilmiah atau scientific evidence yang membutuhkan biaya besar;

5. kesediaan Ahli yang bersedia memberikan keterangan dalam penanganan tindak pidana lingkungan hidup.

Dalam menghadapi kendala-kendala tersebut maka diperluka ekstra kerja keras dari para penegak hukum.Polri merupakan bagian dari penegak hukum sebagaimana Undang Undang Nomor 2 Tahun 2002 Tentang Kepolisian Pasal 1 ayat 2 yang isinya adalah: "Kepolisian Negara Republik Indonesia, selanjutnya disebut Kepolisian Negara, ialah alat Negara penegak hukum yang terutama bertugas memelihara keamanan di dalam negeri”. Pengembanan tugas Negara sebagaimana termaktub dalam pasal ini menuntut kemampuan teknis Polri sebagai Penyidik Tindak Pidana Lingkungan khususnya yang memadai dalam pengumpulan bukti-bukti atas terjadinya suatu tindak pidana di bidang perlindungan dan pengelolaan lingkungan hidup, juga diharapkan memiliki pemahaman yang baik atas peraturan perundang-undangan yang berlaku, sekaligus mampu menjaga integritas, kredibilitas, dan kode etik dalam melaksanakan tugas utamanya, yaitu mencari kebenaran dan menegakkan keadilan demi melindungi kepentingan pelestarian fungsi lingkungan hidup

\section{B. Perumusan Masalah}

Berdasarkan latar belakang yang telah diuraikan di atas, maka rumusan masalah dalam makalah ini adalah Bagaimanakah Polri dalam Mempersiapkan Kemampaun Teknis Personil Penyidik Tindak Pidana Lingkungan Hidup yang memadai ? 


\section{Polri Dalam Mempersiapkan Kemampaun Teknis Personil Penyidik Tindak Pidana Lingkungan Hidup Yang Memadai}

Undang - Undang Nomor: 2 Tahun 2002 Tentang Kepolisian Pasal 1 ayat 2 yang isinya adalah: "Kepolisian Negara Republik Indonesia, selanjutnya disebut Kepolisian Negara, ialah alat Negara penegak hukum yang terutama bertugas memelihara keamanan di dalam negeri”. Selanjutnya di Pasal 2 yang isinya adalah sebagai berikut:

Dalam melaksanakan ketentuan-ketentuan dalam pasal 1 maka Kepolisian Negara mempunyai tugas:

(1). a. memelihara ketertiban dan menjamin keamanan umum.

b. mencegah dan memberantas menjalarnya penyakit-penyakit masyarakat.

c. memelihara keselamatan Negara terhadap gangguan dari dalam.

d. memelihara keselamatan orang, benda dan masyarakat, termasuk memberi perlindungan dan pertolongan.

e. mengusahakan ketaatan warga negara dan masyarakat terhadap peraturan-peraturan Negara.

(2). Dalam bidang peradilan mengadakan penyidikan atas kejahatan dan pelanggaran menurut ketentuan-ketentuan dalam undang-undang Hukum Acara Pidana dan lainlain peraturan Negara.

(3). Mengawasi aliran - aliran kepercayaan yang dapat membahayakan masyarakat dan Negara.

(4). Melaksanakan tugas-tugas khusus lain yang diberikan kepadanya oleh suatu peraturan Negara.

Kepolisian adalah instansi yang berperan dalam penegakan hukum dan norma yang hidup dalam masyarakat (police as an enforment officer). Pada pelaksanaan demikian, polisi adalah instansi yang dapat memaksakan berlakunya hukum.Manakala hukum dilanggar, terutama oleh perilaku menyimpan yang namanya kejahatan, diperlukan peran polisi untuk memulihkan keadaan (restitutio in intreguman) pemaksa agar sipelanggar hukum menanggung akibat dari perbuatannya. Untuk mengetahui bagaimana hukum ditegakkan tidaklah harus dilihat dari institusi hukum seperti kejaksaan atau pengadilan, tetapi dilihat pada perilaku polisi yang merupakan garda terdepan dari proses penegakkan hukum.Sebagai penegak hukum, polisi adalah 
pribadi atau anggota yang menguasai pengetahuan hukum, bersifat jujur, bersih, berani bertindak dengan penuh tanggungjawab, sehingga hukum dapat ditegakkan.

Terhadap tindak pidana lingkungan diperlukan segera Kepastian dan kecepatan penangan perkara senantiasa tergantung pada masukan sumber daya yang diberikan di dalam program-program pencegahan dan pemberantasan kejahatan. Peningkatan teknologi deteksi kriminalitas, umpamanya mempunyai peranan yang sangat penting bagi kepastian dan kecepatan penangan perkara-perkara pidana lingkungan. Kepolisian sebagai penegak hukum dan juga memiliki kewenangan Kepolisian yang dinamakan diskresi berdasarkan pasal 18 ayat (1) Undang-undang Nomor 2 Tahun 2002 ini merupakan kewenangan yang bersumber dari asas kewajiban umum Kepolisian (plichtmatigheids beginsel) taitu suatu asas yang memberikan kewenangan kepada pejabat kepolisian untuk bertindak atau tidak bertindak menurut penilaiannya sendiri, dalam rangka kewajiban umumnya menjaga, memelihara ketertiban dan menjamin keamanan umum.

Pemahaman tentang "diskresi kepolisian" dalam pasal 18 ayat (1) harus dikaitkan juga dengan konsekuensi pembinaan profesi yang diatur dalam pasal 1, 32, dan 33 Undang-undang Nomor 2 tahun 2002 sehingga terlihat adanya jaminan bahwa petugas Kepolisisan Negara Republik Indonesia akan mampu mengambil tindakan secara tepat dan professional berdasarkan penilaiannya sendiri dalam rangka pelaksanaan tugasnya.Rumusan dalam pasal 18 ayat (2) merupakan rambu-rambu bagi pelaksanaan "diskresi” sebagaimana dimaksud pada ayat (1) yaitu selain asas keperluan, tindakan diskresi tetap harus sesuai dan memperhatikan peraturan perundang undangan serta kode etik profesi Kepolisian Negara Republik Indonesia selain sarana atau fasilitas mempunyai peranan yang sangat penting di dalam penegakan hukum. Tanpa adanya sarana atau fasilitas tersebut, tidak akan mungkin penegakan hukum menyerasikan peranan yang seharusnya dengan peranan yang aktual, maka kepolisian di dalam aspek tugas dan khususnya penataan lingkungan hidup, Polri terkait dalam perananya sebuah fungsi penegakan hukum. Salah satu titik lemah dalam penegakan hukum tindak pidana lingkungan hidup adalah proses penyelidikan dan penyidikan perkaranya, oleh karena itu penulis dalam memberikan masukan, "Postur Penyidik Yang Ideal Dalam Penegakan Hukum Lingkungan Hidup".

Polri menyiapkan jajarannya untuk menghadapi perkembangan permasalahan lingkungan hidup, hal ini di latar belakangi juga oleh faktor pengrusakan dan pencemaran 
lingkungan hidup yang sangat merugikan dan meresahkan masyarakat. Adapun konsepsinya dalam upaya-upaya sebagai berikut:

1. Upaya peningkatan penyidik Polri dalam rangka mengantisipasi tindak pidana lingkungan hidup dengan prioritas para penyidik Polri pada tingkat Bareskrim Polri dan Polda, guna lapis-lapis kekuatan dibidang penyidikan tindak pidana lingkungan hidup.

2. Mewujudkan postur Polri yang profesional, efektif, efisien dan modern dengan penekanan bahwa Polri dibangun untuk menjadi inti kekuatan kamtibmas dan penegakan hukum.

3. Bareskrim Polri menyusun kebijakan dibidang penyidikan, sebagai berikut:

a.Penyidikan harus objektif pada seluruh lapisan masyarakat dan setiap langkah penyidikan tidak boleh ada yang menyimpang.

b. Penyidikan harus dilaksanakan secara konsisten dan mentaati prinsip-prinsip, aturan- aturan yang telah ditetapkan dalam perundang-undangan.

Kemampuan penyidikan tindak pidana lingkungan hidup oleh Polri yang harus ditingkatkan adalah :

1. Ada 3 (tiga) hal yang sangat substansial yang menjadi kelemahannya yaitu :

a. Kemampuan dalam melakukan pengolahan TKP dan penanganan barang bukti kasus pencemaran dan/atau pengrusakan lingkungan hidup.

b. Kemampuan dalam melakukan pemeriksaan terhadap korban, saksi dan tersangka.

c. Kemampuan dalam melakukan transformasi "science evidence" ke dalam "legal evidence" kasus pencemaran lingkungan hidup.

2. Kelemahan-kelemahan secara internal :

a. Kualitas SDM/personil yang masih rendah sebagai penyidik tindak pidana lingkungan hidup, dari segi kuantitas juga masih sangat kurang, karena hingga saat ini ditingkat Polda maupun Polres belum ada satuan/unit khususnya yang menangani kasus tindak pidana lingkungan hidup, demikian halnya di tingkat Mabes Polri baru 30\%kebutuhan personil terpenuhi.

b. Kurangnya pengetahuan dibidang lingkungan hidup, kurang latihan dan sangat jarang atau hampir tidak pernah menangani perkara pemcemaran dan/atau pengrusakan lingkungan hidup.

c. Sistim atau juknis dan juklak masih kurang. 
d. Anggaran, sarana dan prasarana kurang.

3. Fakta-fakta yang ada sangat kontradiktif dengan konsep ideal yang seharusnya dimiliki oleh seorang penyidik tindak pidana lingkungan hidup, yaitu:

a. Sebagai penyidik tindak pidana lingkungan hidup harus menguasai "legal sampling"karena dengan menguasai metode tersebut maka penyidik akan mampu melakukan oleh TKP dan penanganan barang bukti secara cermat dan benar.

b. Harus menguasai materi hukum lingkungan hidup, karena dengan menguasai materi Hukum, maka penyidik akan mampu melakukan pemeriksaan secara benar

4. Untuk memperbaiki kelamahan/kekurangannya maka harus dilakukan upaya-upaya :

a. Para penyidik tindak pidana lingkungan hidup harus diberi pelatihan yang sifatnya "on thespot training" dan "case work training", diharapkan akan menguasai metode "legal sampling" sehingga tak akan mengalami kesulitan dalam hal pengolahan TKP dan penanganan barang bukti.

b. Para penyidik harus diikut sertakan dalam program pendidikan formal, yang relevan dengan pengetahuan konsep bilogi, konsep ekologi, konservasi dan konsep lingkungan hidup melalui pendidikan formal ini diharapkan para penyidik akan mampu melakukan transformasi "science evidence" ke dalam "legal evidence".

Program pendidikan dan pelatihan yang harus dilaksanakan, adalah:

1. Polri khususnya Bareskrim melaksanakan kerja sama pelatihan dengan Bapedal setiap wilayah, Kejaksaan Agung dan Mahkamah Agung dan Kementerian Negara Lingkungan Hidup.

2. Dalam melaksanakan/menyelenggarakan pendidikan spesialis Reserse Lingkungan Hidup adanya penyempurnaan bahan pelajarannya terutama berkaitan dengan Peraturan perundang-undangan, Peraturan Menteri, Kebijakan pemerintah daerah dikarenakan adanya otonomi daerah berdasarkan Undang Undang Nomor 32 Tahun 2004 tentang Pemerintahan Daerah sehingga hal ini mempengaruhi terhadap kebijakan-kebijakan daerah yang berbeda-beda dan hubungannya dengan lingkungan hidup adalah berkaitan dengan rencana pembangunan suatu daerah.

3. Kepolisian melakukan pengorganisasian berupa pembentukan unit penyidik lingkungan hidup untuk Polres dan satuan penyidik lingkungan hidup untuk tingkat Polda, untuk 
mengisi struktur tersebut dilakukan rekrutmen personil baru yang mempunyai latar belakang yang relevan dengan bidang hukum lingkungan dan ilmu lingkungan

\section{KESIMPULAN}

Polri dalam mengemban tugas sebagai alat Negara untuk menegakkan hukum dalam kehidupan sehari-hari terhadap perilaku perseorangan atau kelompok, ataupun korporasi yang dapat mengganggu ketertiban dan keamanan umum khususnya untuk tindak pidana lingkungan hidup sangat diperlukan sekali personal polri yang dapat memahami tentang perkara ini terutama dalam proses penyidikan dan penyelidikan bahwa telah terjadi pengrusakan lingkungan dikarenakan lingkungan merupakan bagian ekosistem yang dapat berdampak fatal bagi kehidupan manusia pada wilayah terdekat tercemar dan dampak umum bagi kehidupan makhluk hidupnya. Polri melalui Bareskrim telah mempersiapkan personal yang memahami tentang undang undang lingkungan hidup Peraturan Menteri, Pemerintahan Daerah dan melakukan kerjasama dengan lembaga-lembaga pemerintah seperti Bapedalda yang terdapat didaerahdaerah, Kementerian Negara Lingkungan Hidup dan bekerja sesuai dengan kode etik dan benarbenar memanfaatkan kewenangan diskresi yang dimiliki oleh Polri dengan tepat dalam memberikan penilaian terhadap perkara pidana lingkungan.

\section{E. DAFTAR PUSTAKA}

Andi Hamzah, Sistem Pidana dan Pemidanaan Indonesia. Pradnya Paramita, Jakarta. 1993 Barda Nawawi Arif, Bunga Rampai Kebijakan Hukum Pidana, Undip, Semarang. 1996.

Roeslan Saleh, Tentang Tindak-Tindak Pidana dan Pertanggungan Jawab Pidana, BPHN, Jakarta, 1984.

RM. Gatot P Soemartono. Hukum Lingkungan Indonesia. Penerbit Sinar Grafika. Jakarta, 2002.

Otto Soemarwoto. Ekologi Lingkungan Hidup dan Pembangunan, PT. Djambatan. Jakarta. 2004. 